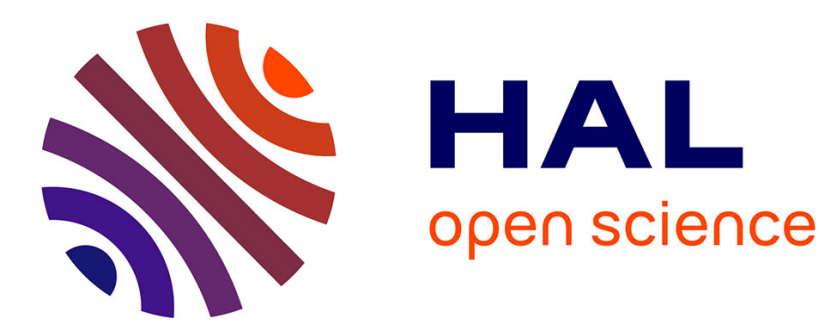

\title{
Structure of germanene/Al(111): a two-layers surface alloy
}

K. Zhang, D. Sciacca, M.-C. Hanf, R. Bernard, Yves Borensztein, A. Resta, Y. Garreau, A. Vlad, A. Coati, Isabelle Lefebvre, et al.

\section{- To cite this version:}

K. Zhang, D. Sciacca, M.-C. Hanf, R. Bernard, Yves Borensztein, et al.. Structure of germanene/ $\mathrm{Al}(111)$ : a two-layers surface alloy. Journal of Physical Chemistry C, 2021, 10.1021/acs.jpcc.1c07585 . hal-03416904

\section{HAL Id: hal-03416904 https://hal.sorbonne-universite.fr/hal-03416904}

Submitted on 5 Nov 2021

HAL is a multi-disciplinary open access archive for the deposit and dissemination of scientific research documents, whether they are published or not. The documents may come from teaching and research institutions in France or abroad, or from public or private research centers.
L'archive ouverte pluridisciplinaire HAL, est destinée au dépôt et à la diffusion de documents scientifiques de niveau recherche, publiés ou non, émanant des établissements d'enseignement et de recherche français ou étrangers, des laboratoires publics ou privés. 


\section{Structure of germanene/Al(111): a two-layers}

\section{surface alloy}

K. Zhang, ${ }^{\#}$ D. Sciacca, ${ }^{\dagger}$ M.-C. Hanf, ${ }^{\& s}$ R. Bernard, ${ }^{\#}$ Y. Borensztein, ${ }^{\#}$ A. Resta, ' Y. Garreau,

A. Vlad, 'A. Coati, 'I. Lefebvre, ${ }^{\dagger}$ M. Derivaz, ${ }^{\&}$ C. Pirri, ${ }^{\text {\& }}$ P. Sonnet, ${ }^{\text {\& }}$ R. Stephan, ${ }^{\text {\& }}$ G. Prévot $^{\# *}$

* Sorbonne Université, Centre National de la Recherche Scientifique, Institut des NanoSciences de Paris, INSP, F-75005 Paris, France

\& Université de Haute Alsace, CNRS, IS2M UMR7361, F-68100 Mulhouse, France

${ }^{\S}$ Université de Strasbourg, France

- Synchrotron SOLEIL, L’Orme des Merisiers Saint-Aubin, BP 4891192 Gif-sur-Yvette Cedex, France

\section{Supporting Information}

\section{Details of the minimization procedure used for exploring all configurations.}

In order to determine the structure of the surface, we have tested all possible configurations involving as well $\mathrm{Al}$ and $\mathrm{Ge}$ atoms in a bilayer configuration on top of a $\mathrm{Al}(111)$ substrate. For the first layer (surface plane), we have explored any position of the atoms that respects the space group symmetries, assuming at least $3 \mathrm{Ge}$ atoms and at most 9 atoms in the surface layer. We have assumed that the space group was the same as the one of the substrate, i.e. p3m1. Configurations are defined by the occupancy of $1 a, 1 b, 1 c, 3 d$ and $6 e$ Wyckoff positions. ${ }^{1}$ Within these assumptions, the number of different configurations for the surface 
plane is 118. For the second layer (interfacial plane), we have started from the atomic positions of an $\mathrm{Al}(111)$ plane where at most three $\mathrm{Al}$ atoms are replaced with $\mathrm{Ge}$ atoms, also respecting the $\mathrm{p} 3 \mathrm{~m} 1$ symmetries. For an Al plane, there are three possible atomic configurations for the 9 atoms inside a $(3 \times 3)$ cell. They are drawn in Fig. S1a-c. The first one corresponds to atoms belonging to the Wyckoff positions $1 a, 1 b, 1 c$, and $6 e$. The two other configurations correspond to three groups of atoms in $3 d$ positions.
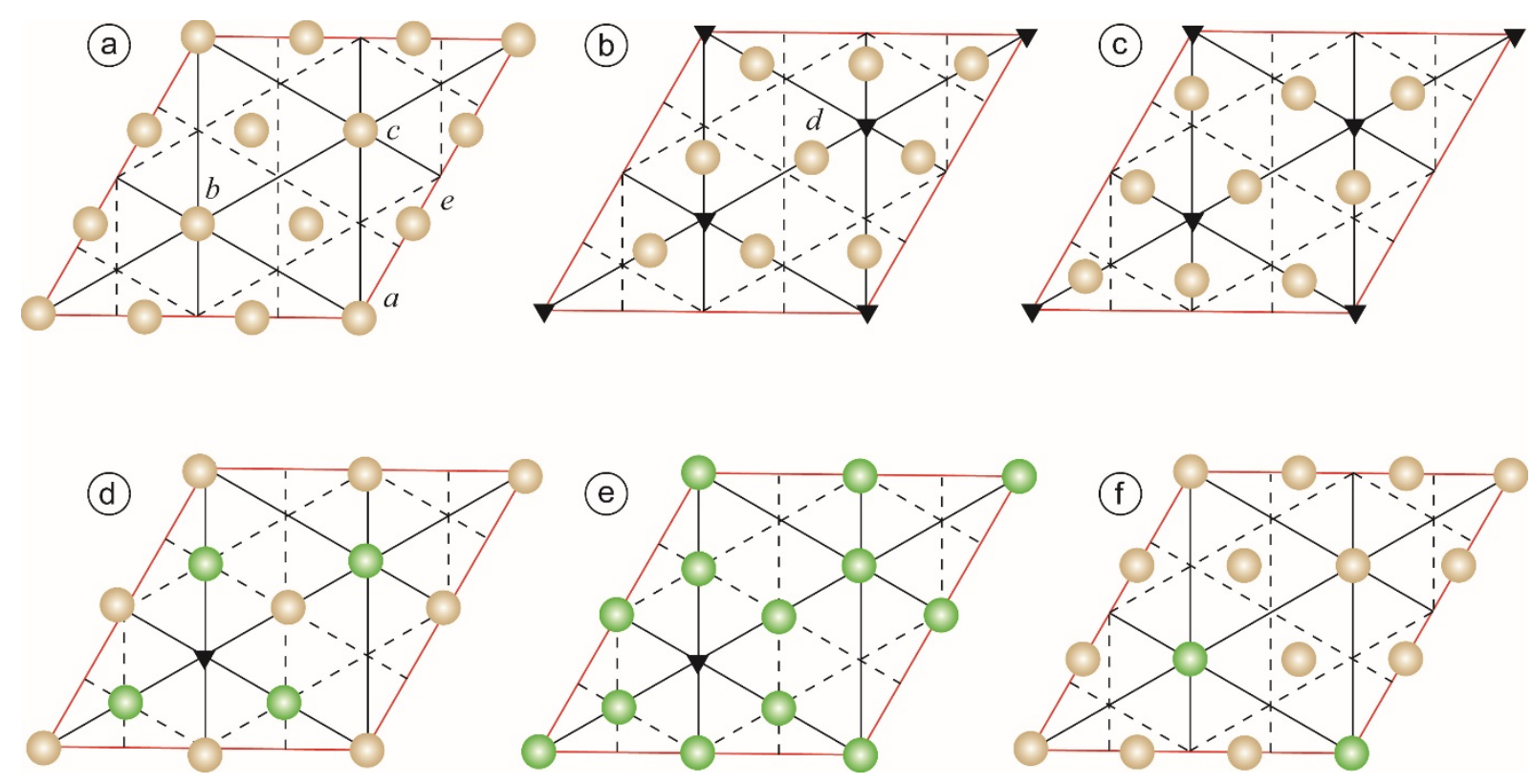

Figure S1: (a-c) atomic configurations for $\mathrm{Al}(111)$ planes respecting the $\mathrm{p} 3 \mathrm{~m} 1$ symmetries. (d) $\mathrm{Ge}_{4} \mathrm{Al}_{4}$ surface plane. (e) $\mathrm{Ge}_{8}$ surface plane. (f) $\mathrm{Ge}_{2} \mathrm{Al}_{7}$ interfacial plane. The $(3 \times 3)$ unit cell is drawn in red, $\mathrm{Al}$ atoms are drawn in brown, Ge atoms in green. Wyckoff positions are indicated by $a, b, c, d$, e letters. Mirror and glide planes are drawn in black continuous and dotted lines respectively. Triangles indicate 3 -fold rotation axes. 
The maximum relaxation allowed for atoms of the interface plane was $\pm 10 \%$ of the unit cell size. The third layer was considered as a pure Al plane, where atoms could relax with a maximum amplitude of $5 \%$ of the unit cell size. Debye Waller factors were used for the description of atomic vibrations in directions parallel or perpendicular to the surface. DebyeWaller factors were set independent for each group of symmetrical atoms within the first two planes, and equal for atoms of the third plane.

For each configuration tested, the best fit of the structure factors has been obtained by exploring the space of free parameters (a scale factor, the atomic positions and Debye-Waller factors) using the genetic algorithm implemented in SciPy. The agreement was obtained by minimizing $\sum\left(\frac{F_{\text {th }}-F_{\text {exp }}}{\sigma_{\text {exp }}}\right)^{2}+E$, where $F_{\text {exp }}$ and $F_{\text {th }}$ are the experimental and simulated structure factors, $\sigma_{\exp }$ the experimental uncertainties and where $E$ is a dimensionless Lennard-Jones interaction energy between nearest-neighbors atoms. $E$ is given by:

$$
E=\sum_{\substack{i, j \\ d_{i j}<1.1 d_{0}}} A\left[\left(\frac{d_{0}}{d_{i j}}\right)^{12}-2\left(\frac{d_{0}}{d_{i j}}\right)^{6}+C\right]
$$

where $d_{i j}$ is the distance between atoms $i$ and $j . A$ and $d_{0}$ depends on the chemical nature of atoms $i$ and $j$ and are given in table S1. $C$ is a constant term equal to $2 \times 1.1^{-6}-1.1^{-12}$ used to avoid any discontinuity of the interaction at the cutoff value.

\begin{tabular}{|l|l|l|}
\hline$(i, j)$ & $A$ & $d_{0}(\mathrm{~nm})$ \\
\hline Al-Al & 5 & 0.286 \\
\hline Ge-Ge & 1 & 0.245 \\
\hline Al-Ge & 2 & 0.266 \\
\hline
\end{tabular}

Table S1: parameters for the Lennard-Jones interaction 


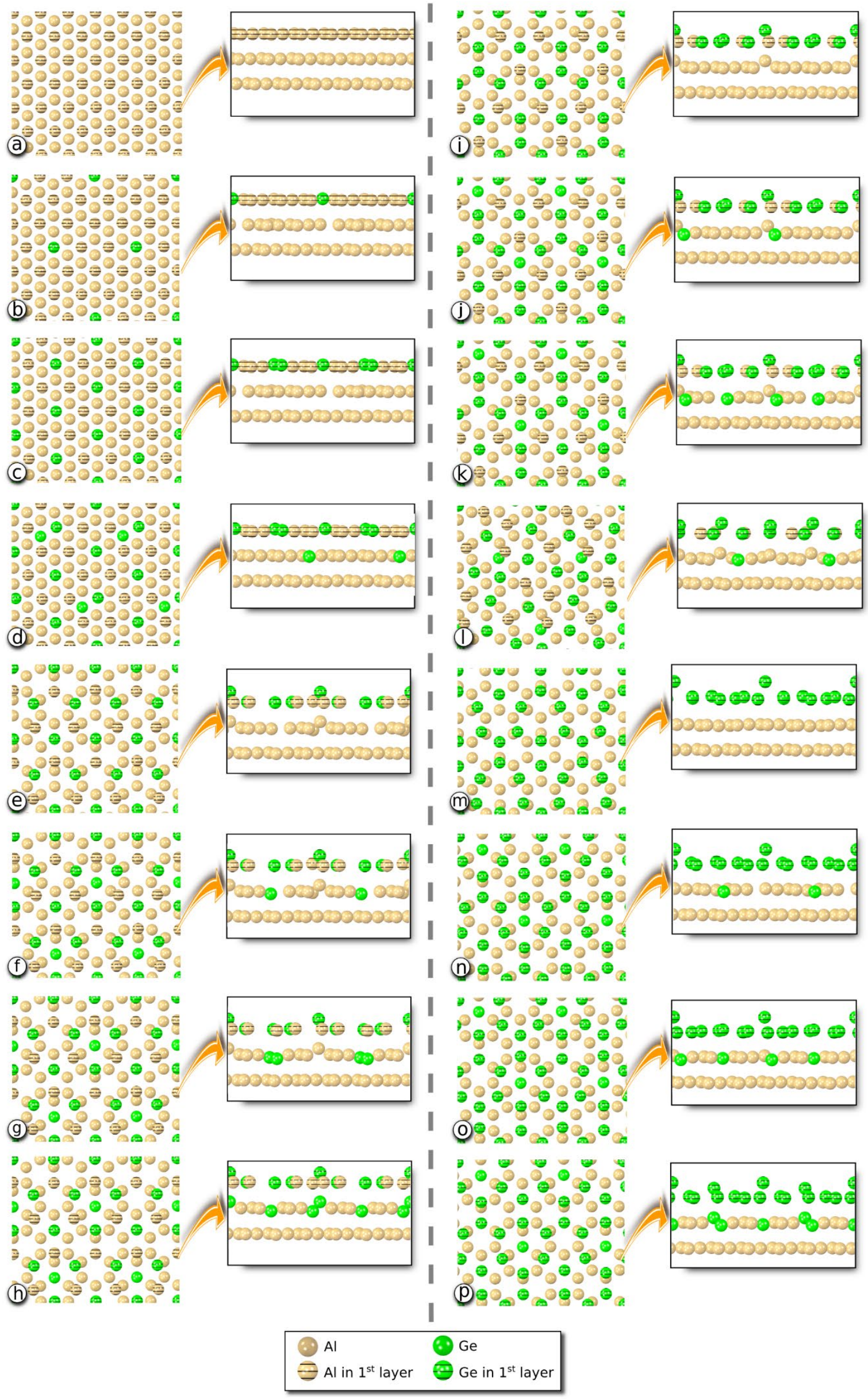


Figure S2: Models of Ge layers on Al(111) relaxed by DFT. (a) pure Al, (b) $\mathrm{Ge}_{1} \mathrm{Al}_{8} / \mathrm{Al}_{9}$, (c) $\mathrm{Ge}_{3} \mathrm{Al}_{6} / \mathrm{Al}_{9}$, (d) $\mathrm{Ge}_{3} \mathrm{Al}_{6} / \mathrm{Ge}_{1} \mathrm{Al}_{8}$, (e) $\mathrm{Ge}_{4} \mathrm{Al}_{4} / \mathrm{Al}_{9}$, (f) $\mathrm{Ge}_{4} \mathrm{Al}_{4} / \mathrm{Ge}_{1} \mathrm{Al} 1_{8}$, (g) $\mathrm{Ge}_{4} \mathrm{Al}_{4} / \mathrm{Ge}_{2} \mathrm{Al}_{7}$, (h) $\mathrm{Ge}_{4} \mathrm{Al}_{4} / \mathrm{Ge}_{3} \mathrm{Al}_{6}$, (i) $\mathrm{Ge}_{5} \mathrm{Al}_{3} / \mathrm{Al}_{9}$, (j) $\mathrm{Ge}_{5} \mathrm{Al}_{3} / \mathrm{Ge}_{1} \mathrm{Al}_{8},(\mathrm{k}) \mathrm{Ge}_{5} \mathrm{Al}_{3} / \mathrm{Ge}_{2} \mathrm{Al}_{7}$, (l) $\mathrm{Ge}_{5} \mathrm{Al}_{4} / \mathrm{Ge}_{1} \mathrm{Al}_{8}$, (m) $\mathrm{Ge}_{8} / \mathrm{Al}_{9}(1 \mathrm{H}),(\mathrm{n}) \mathrm{Ge}_{8} / \mathrm{Ge}_{1} \mathrm{Al}_{8},(\mathrm{o}) \mathrm{Ge}_{8} / \mathrm{Ge}_{2} \mathrm{Al}_{7}$, (p) $\mathrm{Ge}_{8} / \mathrm{Ge}_{3} \mathrm{Al}_{6}$. The side views correspond to a projection along a plane $7^{\circ}$ off from the $(11 \overline{2})$ plane. 